\title{
A CLINICAL STUDY OF BEAT KNEE
}

\author{
BY \\ J. T. WATKINS, T. A. HUNT, R. H. P. FERNANDEZ, and O. P. EDMONDS \\ From the Medical Department, East Midlands Division, National Coal Board
}

(RECEIVED FOR PUBLICATION MAY 21, 1957)

Beat knee is defined as " a subcutaneous cellulitis or acute bursitis arising at or about the knee" in the First Schedule to the National Insurance (Industrial Injuries) (Prescribed Diseases) Regulations, 1948. The cases considered in this paper all fell within this definition.

Our continued observation of many miners with beat knee who attended medical treatment centres at mines suggested that there were well-defined clinical patterns not described in the accepted broad classifications of previous writers (Collis and Llewellyn, 1924; Watkins, 1951; Atkins and Marks, 1952; Watkins and Hunt, 1954).

With the object of confirming this suggestion, a systematic study was undertaken for 18 months in 1954-55 of cases of beat knee occurring in a large group of mines, mainly in the North Derbyshire coal fields, employing 17,899 men underground. A total of 899 cases of beat knee occurred in this period, and were included in the study; there was no selection. It was also felt that a detailed clinical study might throw more light on the relationship of beat knee to the working environment of the miner. The clinical findings in each case were recorded separately, with relevant personal and environmental data. The state registered nurses in charge of medical treatment centres were given intensive tuition in the recognition of the different clinical types of beat knee, and issued with a set of photographs illustrating each main type. Any case in which the classification was doubtful was examined and classified by a medical officer. After checking for completion, the records were transferred to Powers-Samas punched cards for statistical analysis.

\section{The Knee in Coal-miners}

It is frequently impossible for the coal-miner to work standing, and in some places he must work lying down. He is often compelled to work in the kneeling position during the whole of his shift of seven hours because of the low height of the coalface. His kneeling posture varies according to the task in which he is engaged, and according to personal preference; but kneel he must, and while kneeling, he transmits his body weight through his knees on to the floor of the coalface, which is carpeted with coal fragments. Changes in the kneeling posture distribute the body weight through different angles, and pressure may therefore be exerted at different points in the knee area.

In the past the emphasis in causation of beat knee has been placed mainly on abrasions of the skin caused by sharp coal particles, with subsequent infection of the underlying tissues. The effects of continued and repeated local pressures have received less attention.

\section{Clinical Classification}

Pain is the predominant symptom in all cases. It brings the miner for treatment and sends him off work. The chief clinical features of beat knee are a bursitis and a cellulitis in the region of the knee, existing separately or together. Our belief that these were separate clinical types of beat knee was confirmed, and it was found that all cases could be included in three main clinical groups. Further division of these enabled 11 clinical types of beat knee to be identified. The main groups and their seven subdivisions are shown in Table 1 , which also gives the number of cases in each category.

TABLE 1

CLINICAL TYPES OF BEAT KNEE

\begin{tabular}{|c|c|c|c|}
\hline$\underset{\text { Clinical Type }}{\text { Main }}$ & Subdivision & $\begin{array}{l}\text { No. of } \\
\text { Cases }\end{array}$ & $\begin{array}{l}\% \text { Total } \\
\text { Cases }\end{array}$ \\
\hline Simple bursitis & $\begin{array}{l}\text { Suprapatellar } \\
\text { Prepatellar } \\
\text { Infrapatellar }\end{array}$ & $\left.\begin{array}{r}41 \\
389 \\
202\end{array}\right\} 632$ & $70 \cdot 3$ \\
\hline Cellulitis & $\begin{array}{l}\text { Diffuse } \\
\text { Local }\end{array}$ & $\left.\begin{array}{r}5 \\
98\end{array}\right\} 103$ & $11 \cdot 5$ \\
\hline \multirow[t]{2}{*}{$\begin{array}{l}\text { Combined } \\
\text { Bursitis and } \\
\text { cellulitis }\end{array}$} & $\begin{array}{l}\text { Diffuse }\left\{\begin{array}{l}\text { Suprapatellar } \\
\text { Prepatellar } \\
\text { Infrapatellar }\end{array}\right. \\
\text { Local }\left\{\begin{array}{l}\text { Suprapatellar } \\
\text { Prepatellar } \\
\text { Infrapatellar }\end{array}\right.\end{array}$ & $\left.\begin{array}{r}3 \\
35 \\
27 \\
7 \\
46 \\
46\end{array}\right\} 164$ & $18 \cdot 2$ \\
\hline & Total & 899 & $100 \cdot 0$ \\
\hline
\end{tabular}


Simple Bursitis.-The bursae were clearly defined when they were distended with fluid and the overlying skin showed no sign of inflammation. Three anatomical types could be clearly differentiated on clinical examination and together formed $70.3 \%$ of the total beat knee cases.

(1) The suprapatellar bursa extends upwards from the upper margin of the patella deep to the quadriceps.

(2) The prepatellar bursa lies mainly in front of the patella and its ligament. When it is distended with fluid this bursa can usually be distinguished without difficulty from the infrapatellar bursa which lies in front of the tibial tubercle and the tendon insertion. In the majority of cases the clinical differentiation can be made by the simple test of placing the finger immediately across and below the line of the lower border of the patella, thus defining the position of the distended bursa.

(3) There is also a deep infrapatellar bursa, small and of little importance, lying between the patellar tendon and the upper part of the tibial tubercle. When enlarged, it protrudes along the lateral margins of the patellar tendon. This is grouped clinically with infrapatellar bursitis as it is rarely seen alone.

Cellulitis.-Diffuse cellulitis spreading over the front of the knee was unmistakable. Local cellulitis differed in extent only, and often merged imperceptibly into a boil or an infected abrasion. This group represented only $11.5 \%$ of the beat knee cases.

Combined Bursitis and Cellulitis.-Cellulitis was present in a local or diffuse form together with enlargement of the adjacent bursa in $18.2 \%$ of the total cases.

\section{Recurrence}

During the 18-month period of our study 80 men had between them 92 recurrences of beat knee. Eleven men had two recurrences, and one had three. Of the 80 men who experienced recurrences, 59 had simple bursitis in their first attack. Eleven of the recurrences in these 59 were due to cellulitis. The remaining 21 had cellulitis in their first attack, and 15 of the recurrences in this group were also due to cellulitis.
It is interesting to note that of the 59 recurrences in the simple bursitis cases, 48 recurred at the same site. This may have been due to the fact that a miner, who is compelled to kneel at his work, establishes by experience and possibly advice from his colleagues a kneeling posture which, once he has accustomed himself to it, remains with him as an established working posture.

\section{Relation to Environment}

The incidence of beat knee in our series varied widely between collieries, the lowest being 13.25 per 1,000 men underground, and the highest 105.4 per 1,000 men underground. This wide variation suggested that environmental differences might be important.

Occupation.-When the cases were classified by occupation it was found that $96 \%$ occurred in coalface workers who represented only $54 \%$ of the total underground labour force (Table 2). Coal-getters comprised only $25 \%$ of the total underground labour force, but contributed $57 \cdot 1 \%$ of the cases.

TABLE 2

OCCUPATIONAL ANALYSIS OF BEAT KNEE CASES

\begin{tabular}{|c|c|c|}
\hline Occupation & No. of Cases & $\%$ Total Cases \\
\hline $\begin{array}{l}\text { Coal-face workers: } \\
\text { Coal-getters } \\
\text { Drillers } \\
\text { Shotfirers and deputies } \\
\text { Conveyor shifters } \\
\text { Coal cutter men } \\
\text { Rippers and packers } \\
\text { Other faceworkers } \\
\text { Other underground workers }\end{array}$ & $\begin{array}{r}513 \\
25 \\
39 \\
25 \\
24 \\
174 \\
66 \\
33\end{array}$ & $\begin{array}{r}57 \cdot 1 \\
2 \cdot 8 \\
4 \cdot 3 \\
2 \cdot 8 \\
2 \cdot 7 \\
19 \cdot 3 \\
7 \cdot 3 \\
3 \cdot 7\end{array}$ \\
\hline Total & 899 & $100 \cdot 0$ \\
\hline
\end{tabular}

Rippers and packers together comprised about the same number of faceworkers as coal-getters, yet they produced only $19 \cdot 3 \%$ of the cases compared with $57.1 \%$ among coal-getters. This is presumably due to the fact that rippers and packers do not kneel as long as the coal-getters.

Coal-face Height.-The incidence of beat knee at the pits included in our study varied according to the height of the seam at the coal-face. We could find no inter-relationship between the occupation of the miner, his age, and the seam thickness.

TABLE 3

PERCENTAGE OF CASES BY CLINICAL CONDITION AND COAL-FACE HEIGHT IN COAL-FACE WORKERS ONLY

\begin{tabular}{|c|c|c|c|c|c|c|c|c|c|}
\hline \multirow{3}{*}{ Seam $\mathbf{r}$} & \multirow{3}{*}{ Height } & & & \multirow{3}{*}{$\begin{array}{l}\text { No. of Beat } \\
\text { Knee Cases }\end{array}$} & \multicolumn{5}{|c|}{$\%$ Cases in Each Clinical Type } \\
\hline & & & & & \multicolumn{3}{|c|}{ Simple Bursitis } & \multirow{2}{*}{ Cellulitis } & \multirow{2}{*}{$\begin{array}{l}\text { Combined Cellulitis } \\
\text { and Bursitis }\end{array}$} \\
\hline & & & & & Suprapatellar & Prepatellar & Infrapatellar & & \\
\hline $4 \mathrm{ft}$. and over $\ldots$ & $\therefore$ & $\because$ & $\begin{array}{l}\cdots \\
.\end{array}$ & $\begin{array}{l}662 \\
204 \\
\end{array}$ & $\begin{array}{l}5 \\
3 \\
\end{array}$ & $\begin{array}{l}41 \\
50\end{array}$ & $\begin{array}{l}23 \\
19\end{array}$ & $\begin{array}{r}9 \\
19 \\
\end{array}$ & 22 \\
\hline Total & $\ldots$ & $\ldots$ & .. & 866 & 4 & 44 & 22 & 11 & 19 \\
\hline
\end{tabular}




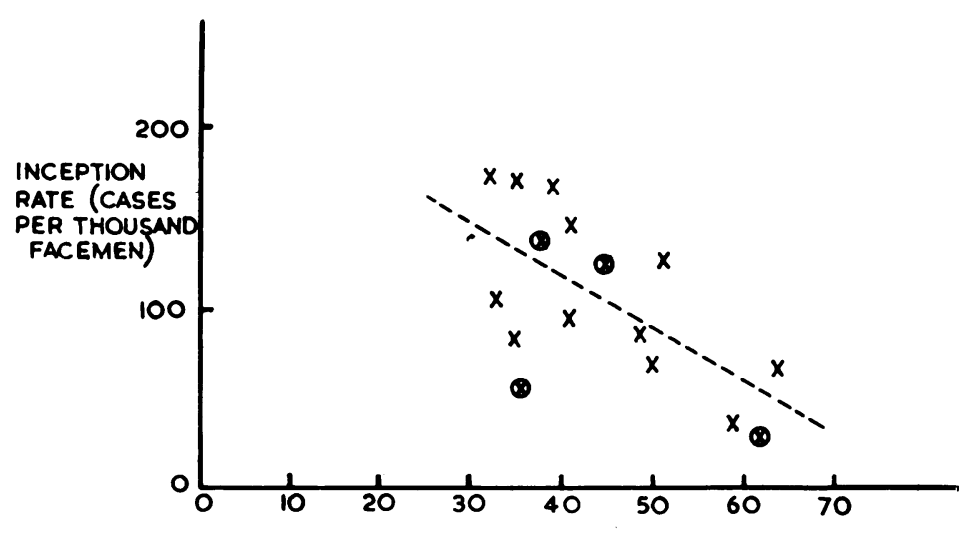

average seam height (InChes)

Fic. 1.-Inception rates of beat knee by seam height in faceworkers only in 18 months at 16 collieries.

Collieries not using predominantly the most common method of mining are circled.

Fig. 1 and Table 3 indicate that the incidence of beat knee is related to seam height. They show the increased incidence of cases of beat knee in the thinner seams. Seventy-six per cent. of all cases in the series reviewed occurred in men working in heights less than $4 \mathrm{ft}$., while only $63 \%$ of the total man shifts were worked in these heights. The findings emphasize the importance of coal-face heights as an environmental factor in the causation of beat knee. The reason is the difficulty which the coal-face worker in low seams has in adopting, for working comfort, any other posture than kneeling.

\section{Protective Equipment}

The varieties of knee pads worn by faceworkers were of four main types: (a) Rubber-lined cup, (b) felt-lined pads, $(c)$ bursa pads, $(d)$ trouser pads. Eight hundred and twenty-one faceworkers in the cases under review during the period wore knee pads; 45 faceworkers did not. Rubber-lined cups and felt-lined pads were those most commonly used;

TABLE 4

CLINICAL CONDITION AND TYPE OF KNEE PAD WORN BY FACEWORKERS ONLY

\begin{tabular}{|c|c|c|c|c|c|c|}
\hline \multirow[t]{2}{*}{$\begin{array}{l}\text { Clinical } \\
\text { Condition }\end{array}$} & $\begin{array}{l}\text { No } \\
\text { Pads } \\
\text { Used }\end{array}$ & $\begin{array}{c}\text { Bursa } \\
\text { Pads }\end{array}$ & $\begin{array}{c}\text { Rubber- } \\
\text { lined } \\
\text { Cups }\end{array}$ & $\begin{array}{l}\text { Felt- } \\
\text { lined } \\
\text { Pads }\end{array}$ & $\begin{array}{l}\text { Trouser } \\
\text { Pads }\end{array}$ & Total \\
\hline & Cases & Cases & Cases & Cases & Cases & Cases \\
\hline $\begin{array}{l}\text { Simple } \\
\text { bursitis } \\
\text { Cellulitis } \\
\text { Combined } \\
\text { bursitis and } \\
\text { I cellulitis }\end{array}$ & $\begin{array}{r}32 \\
8\end{array}$ & $\begin{array}{r}145 \\
18\end{array}$ & $\begin{array}{r}233 \\
31 \\
\\
67\end{array}$ & $\begin{array}{r}195 \\
39 \\
\\
53\end{array}$ & -3 & $\begin{array}{r}608 \\
96 \\
162\end{array}$ \\
\hline Total.. & 45 & 200 & 331 & 287 & 3 & 866 \\
\hline
\end{tabular}

only a few men used trouser pads. No association was found between clinical condition and the type of pad worn (Table 4).

It is evident that these types of knee pads do not prevent beat knee in coal-miners who must work in a kneeling position.

\section{Age}

Table 5 shows that younger men are more susceptible to beat knee than older men. Two reasons might account for this: one, that the knee, through constant use, adjusts itself to withstanding the pressures of coal-face work in a limited height; the second, that getting coal is the most physically arduous task as well as the occupation most susceptible to beat knee, and this is

TABLE 5

AGE-GROUP ANALYSIS

\begin{tabular}{|c|c|c|c|c|c|}
\hline $\begin{array}{c}\text { Age } \\
\text { Group }\end{array}$ & $\begin{array}{l}\text { No. of } \\
\text { Under- } \\
\text { ground } \\
\text { Workers } \\
\text { on } \\
\text { Books }\end{array}$ & $\begin{array}{c}\text { No. } \\
\text { of } \\
\text { Cases } \\
\text { of } \\
\text { Beat } \\
\text { Knee }\end{array}$ & $\left|\begin{array}{c}\text { No. of } \\
\text { Cases } \\
\text { per } \\
1,000 \\
\text { Men } \\
\text { on Books }\end{array}\right|$ & $\begin{array}{l}\text { No. of } \\
\text { Shifts } \\
\text { Lost }\end{array}$ & $\begin{array}{c}\text { Average } \\
\text { No. of } \\
\text { Shifts } \\
\text { Lost } \\
\text { per } \\
\text { Case }\end{array}$ \\
\hline $\begin{array}{l}\text { All Cases: } \\
\text { Under } 21 \\
21-25 \\
26-30 \\
31-40 \\
41-50 \\
51-60 \\
61-64 \\
65 \text { and over }\end{array}$ & $\begin{array}{r}1,785 \\
1,634 \\
2,050 \\
4,268 \\
4,054 \\
3,073 \\
762 \\
273\end{array}$ & $\begin{array}{r}126 \\
141 \\
182 \\
218 \\
150 \\
70 \\
11 \\
1\end{array}$ & $\begin{array}{r}70 \cdot 6 \\
86 \cdot 3 \\
88 \cdot 8 \\
51 \cdot 1 \\
37 \cdot 0 \\
22 \cdot 8 \\
14 \cdot 4 \\
3 \cdot 7\end{array}$ & $\begin{array}{r}594 \\
785 \\
562 \\
1,341 \\
1,016 \\
719 \\
101 \\
-\end{array}$ & $\begin{array}{r}4 \cdot 7 \\
5 \cdot 6 \\
3 \cdot 1 \\
6 \cdot 2 \\
6 \cdot 8 \\
10 \cdot 3 \\
9 \cdot 2 \\
-\end{array}$ \\
\hline Total for all ages & 17,899 & 899 & $50 \cdot 2$ & 5,118 & $5 \cdot 7$ \\
\hline $\begin{array}{l}\text { Coal-face Worke } \\
\text { Under } 21 \\
21-25 \\
26-30 \\
31-40 \\
41-50 \\
51-60 \\
61-64 \\
65 \text { and over }\end{array}$ & $\begin{array}{r}\text { Only: } \\
506 \\
1,159 \\
1,583 \\
3,171 \\
2,551 \\
1,337 \\
193 \\
23\end{array}$ & $\begin{array}{r}123 \\
137 \\
177 \\
215 \\
143 \\
61 \\
10 \\
-\end{array}$ & $\begin{array}{r}243 \\
118 \\
112 \\
68 \\
56 \\
46 \\
52 \\
\end{array}$ & $\begin{array}{r}594 \\
745 \\
533 \\
1,322 \\
987 \\
622 \\
92 \\
-\end{array}$ & $\begin{array}{r}4 \cdot 8 \\
5 \cdot 4 \\
3 \cdot 0 \\
6 \cdot 2 \\
6 \cdot 9 \\
10 \cdot 2 \\
9 \cdot 2 \\
-\end{array}$ \\
\hline Total for all ages & 10,523 & 866 & 82 & 4,895 & $5 \cdot 7$ \\
\hline
\end{tabular}

usually performed by men in the younger age groups. Fig. 2 gives the beat knee inception rates by age for coal-face workers in three different colliery areas for the period of the survey.

\section{Period of Incapacity}

There are many factors which influence the length of time a miner suffering from beat knee may be off work; as in other disabling states, social and personal factors may play their part. Our experience during this review has shown that the presence at a mine of facilities for early diagnosis and adequate treat- 


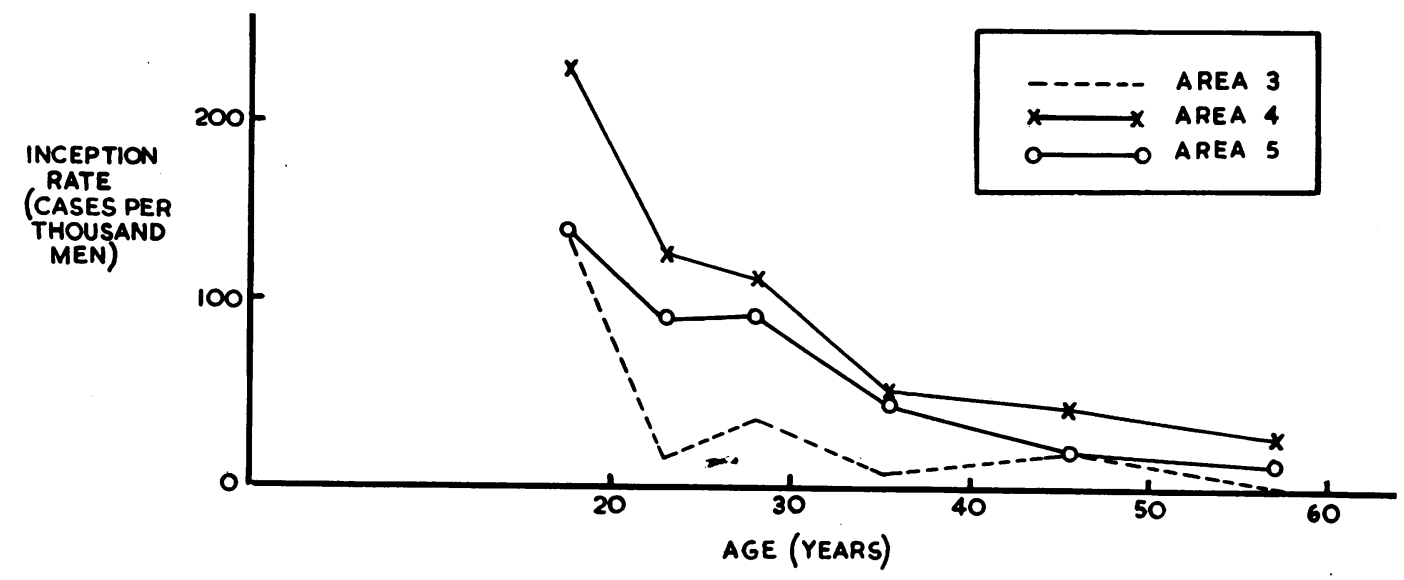

Fig. 2.-Inception rates of beat knee by age in coal-face workers only.

ment considerably reduces the number of shifts lost per case (Table 6).

TABLE 6

PERIOD OF INCAPACITY IN RELATION TO TREATMENT CATEGORY

\begin{tabular}{|c|c|c|c|c|}
\hline Treatment Category & $\begin{array}{c}\text { No. } \\
\text { of } \\
\text { Cases }\end{array}$ & $\begin{array}{c}\% \\
\text { Total } \\
\text { Cases }\end{array}$ & $\begin{array}{l}\text { No. of } \\
\text { Shifts } \\
\text { Lost }\end{array}$ & $\begin{array}{c}\text { Average } \\
\text { No. of } \\
\text { Shifts } \\
\text { Lost per } \\
\text { Case }\end{array}$ \\
\hline $\begin{array}{l}\text { A. Reported to and treated at } \\
\text { colliery medical treatment } \\
\text { centre } \\
B \text { Reported to own doctor } \\
\text { but treated at colliery } \\
\text { medical treatment centre } \\
C \text {. Reported to medical treat- } \\
\text { ment centre but treated } \\
\text { elsewhere } \\
D . \text { Reported to and treated } \\
\text { elsewhere }\end{array}$ & $\begin{array}{r}557 \\
143 \\
95 \\
95\end{array}$ & $\begin{array}{l}62.0 \\
15.9 \\
10.6 \\
11.6\end{array}$ & $\begin{array}{l}1,174 \\
1,247 \\
1,141 \\
1,556\end{array}$ & $\begin{array}{r}2.1 \\
8.7 \\
12.0 \\
15.0\end{array}$ \\
\hline Total & 899 & $100 \cdot 0$ & 5,118 & $5 \cdot 7$ \\
\hline
\end{tabular}

The clinical type of beat knee influences the time lost. For example, a swollen infected bursa often takes longer to resolve than a localized cellulitis limited to the skin and subcutaneous tissues.

The age of the miner suffering from beat knee is of significance. Our results show (Table 5) that in all the cases of beat knee studied, and in those among faceworkers only, the time loss sustained in shifts was greater at the higher ages. One explanation for this may be that for the older person the disability offers the opportunity for a needed rest, not previously acknowledged. We have sometimes found that when persons suffering from beat knee were absent for a long period, the causative factor was social in origin, such as "illness in the home".

The treatment of beat knee is not described here, but we believe that the form of treatment is an important element in determining the amount of time lost. A definite régime was followed in the majority of cases treated in medical treatment centres at collieries (Fernandez, 1958). The value of this régime was proved by the fact that while the average shift loss for all cases was 5.7 shifts, for those treated entirely at medical treatment centres at collieries it was only $2 \cdot 1$ shifts (Tables 5 and 6).

\section{Discussion}

Collis and Llewellyn (1924) stressed the importance of the infective element in beat knee; Atkins and Marks (1952) believed systemic infection to be an important factor in the causation of beat knee. In our series, however, $70.3 \%$ of the cases showed no evidence of infection. This may be due to the fact that the vast majority of men $(94.4 \%)$ wore knee pads, and had bathing facilities at 15 of the 17 collieries reviewed. Thus, the majority of men had facilities for keeping the skin of the knees clean.

Collis and Llewellyn also reported the bursa " over the shin bone" to be most commonly affected, while we have found that the prepatellar bursa was the commonest, $44 \%$, against only $22 \%$ of infrapatellar bursa cases among coal-face workers (Table 3).

Our results show that the coal-face worker most frequently affected is the coal-getter, this group having three times as many cases as the next group, rippers and packers. The coal-filler moves far less on the coal-face than men in the other occupations, and this probably explains why he is more susceptible; his knees are subject to more continuous pressure than those of other coal-face workers.

When a miner kneels, the floor presses against the tibial tuberosity, yet the commonest affected bursa is the prepatellar, an area he does not kneel on; this 
may be due to redistribution of pressure due to knee pads.

We have seen many cases of enlarged bursa aspirated in the early phases, and in the majority of cases altered blood has been drawn off. We believe that the simple, painful bursitis of sudden onset is due to haemorrhage into the bursa, and that this occasionally becomes infected. Where there is no enlargement of the bursa but only infected skin, it is our view that the condition originates in abrasions of the skin which subsequently become infected. Painless enlargement of the bursae is sometimes seen. Such enlargements often persist for long periods, and we agree with Collis and Llewellyn's view that they are harmless. Chronic, painless bursal enlargements probably arise from persistence of an unresolved acute condition.

\section{Summary}

Eight hundred and ninety-nine cases of beat knee occurring in coal-miners at a large group of mines are reviewed. Definite clinical patterns were seen and 11 distinct clinical types are described. Simple bursitis was far more common than the infective condition. The clinical signs were determined by the relative extent of the bursitis element and the infective element. Pain was the dominant symptom.
Beat knee was commonest among young coal-face workers, especially the coal-getter.

Four types of knee pads were worn by coal-face workers at the collieries under review; they were ineffective in the prevention of beat knee.

An average of 5.7 shifts was lost per case; in those cases reporting at, and receiving treatment at, medical treatment centres, only $2 \cdot 1$ shifts were lost per case. In cases not reporting or treated at medical treatment centres, 15 shifts were lost per case. The recurrence rate of beat knee cases during the 18 months of our study was $10 \%$.

Coal-face height was the most important environmental factor in causation.

We are indebted to the East Midlands Division of the National Coal Board for the facilities granted for this investigation. In particular we wish to thank Mr. R. W. Phillips, Divisional Statistical Officer, Mr. W. Cree, and Miss D. H. Jackson for their help with the records, and the state registered nurses and members of the production staff at the mines concerned.

\section{REFERENCES} Atkins, J. B., and Marks, J. (1952). Brit. J. industr. Med., 9, 296.
Collis, E. L., and Llewellyn, T. L. (1924). Spec. Rep. Ser. med. Res. Coun. (Lond.), No. 89.

Fernandez, R. H. P. (1958). Brit. J. industr. Med., 15, 110. Watkins, J. T. (1951). Practitioner, 167, 257. W-, and Hunt, T. A. (1954). Med. Press, 232, 5. 